\title{
ANALISIS PREDIKSI KEBANGKRUTAN DENGAN METODE ALTMAN Z-SCORE PADA PERUSAHAAN RETAIL TRADE YANG TERDAFTAR DI BEI TAHUN 2014-2017
}

\author{
Oleh: \\ Prihatin Gatot Santoso dan Saur Costanius Simamora \\ Mahasiswa dan Dosen Manajemen Unsurya \\ pgatotsantoso@gmail.com dan saurcsimamora@gmail.com
}

\begin{abstract}
This study aims to predict financial distress conditions experienced by retail trade companies listed on the Indonesia Stock Exchange in the period 2014-2017. The population in this study is a retail trade company listed on the Indonesia Stock Exchange for the period 2014-2017. Total sample are seventeen retail trade companies, namely ACES, AMRT, CENT, CSAP, ECII, ERAA, GOLD, HERO, KOIN, LPPF, MAPI, MPPA, RALS, RANC, RIMO, SONA, TELE. Type of descriptive research. The results of the calculation of financial distress analysis with the Altman ZScore method explain consistently that companies that experience financial distress are CENT (2014-2017), GOLD (2015-2017), and RIMO (2014-2016). While companies experiencing grey area conditions are CSAP (2014-2017), ECII (2015-2017), GOLD (2014), and MPPA (2016-2017).

Keywords: financial distress, Altman Z-Score method, financial ratio
\end{abstract}

\section{PENDAHULUAN}

Persaingan ketat antar perusahaan pada saat ini tidak dapat dihindari, dengan demikian perusahaan harus berusaha agar tetap bisa bersaing dan bertahan. Perusahaan yang tidak bisa mempertahankan kinerjanya akan kalah bersaing dengan perusahaan lain yang lebih kompetitif. Lambat laun jika kinerjanya terus menurun perusahaan akan tersingkir dari dunia usaha dan pada akhirnya mengalami kebangkrutan. Salah satu subsektor perusahaan yang sedang mengalami persaingan ketat adalah sub-sektor perusahaan retail. Retail merupakan mata rantai yang penting dalam proses distribusi barang dan merupakan mata rantai terakhir dalam suatu proses distribusi.

Berdasarkan www.republika.com (Utami, 2018:43) menyatakan bahwa sepanjang tahun 2017 menerangkan adanya berita penurunan kinerja sub-sektor retail melalui penutupan gerai-gerai supermarket ataupun toko-toko retail besar di Jakarta, seiring dengan berita penurunan daya beli masyarakat. Riset Nielsen menyebutkan, penjualan Fast Moving Consumer Goods (FMCG) hingga September 2017 hanya tumbuh $2,7 \%$, sedangkan rata-rata pertumbuhan normal tahunan mencapai 11\%. Sementara itu, hingga September 2017 hanya tumbuh $2,7 \%$ atau setara $\mathrm{Rp} 12$ triliun. Itu artinya telah terjadi kerugian penjualan sebesar Rp 37 triliun. Angka kerugian penjualan Rp 37 triliun ini tidak sebanding dengan nilai penjualan FMCG yang hanya sekitar Rp 1,5 triliun.

Ketua Asosiasi Pengusaha Ritel Indonesia (Aprindo), Roy Nicholas Mandey 
dalam wawancara Detik Finance (2018) mengungkapkan bahwa pada tahun 2017 ada sekitar 40 gerai retail yang menutup gerainya dan pada tahun 2018 akan lebih besar yang menutup gerainya yaitu sekitar 50 gerai retail. Roy Nicholas Mandey juga menerangkan kalau tutupnya sejumlah gerai ritel pada tahun lalu, khususnya yang terdaftar sebagai anggota Aprindo lebih dikarenakan relokasi dan reformat gerai. Disebutnya, $80 \%$ penutupan karena relokasi, sementara 20\% karena ingin merubah format bisnis (www.finance.detik-.com, 2018)

\section{Gambar 1. Pertumbuhan Penjualan 10 Emiten Ritel (2013-2017)}

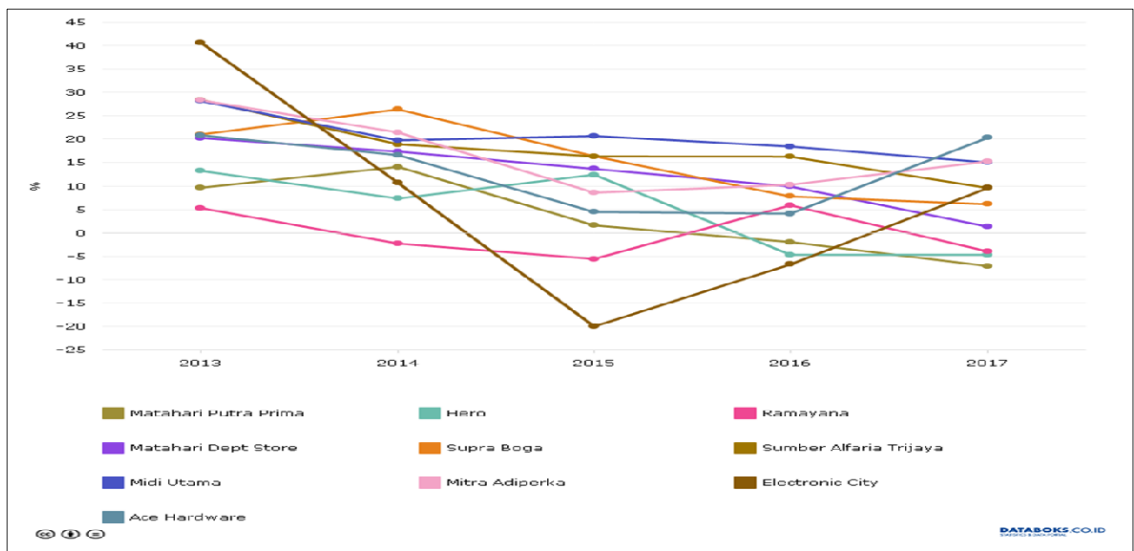

Sumber : www.katadata.co.id

Tahun ini jadi tahun yang berat bagi perusahaan retail di Indonesia. Sebab, banyak perusahaan retail yang menutup sebagian toko atau bahkan sampai gulung tikar. Detik Finance (www.finance.detik.com, 2017) mencatat beberapa perusahaan yang terpaksa harus menutup gerainya, antara lain : manajemen PT Modern Internasional Tbk (MDRN) menutup seluruh gerai 7-Eleven yang di bawah anak usaha perseroan yaitu PT. Modern Sevel Indonesia. Penutupan seluruh gerai 7-Eleven (Sevel) di Indonesia mulai dilakukan 30 Juni 2017. Hingga Maret 2017, perseroan mencatatkan rugi Rp 447,93 miliar kepada pemilik entitas induk. Selain itu PT Modern Internasional Tbk juga alami penurunan penjualan $37,17 \%$ dari $\mathrm{Rp} 220,66$ miliar pada kuartal I 2016 menjadi Rp 138,62 miliar pada kuartal I 2017.

Sindo News (www.sindonews.-com, 2017) juga menyebutkan PT Matahari Putra Prima Tbk telah menutup dua gerai Hypermart yang dianggap tak menguntungkan pada Juli 2017. Penutupan dua gerai itu disebabkan berbagai faktor, salah satunya lokasi yang sudah tidak mendukung. PT Matahari Department Store Tbk (LPPF) menutup dua gerainya di kawasan Pasaraya Blok M dan Manggarai pada akhir September 2017. Keputusan ini diambil karena perusahaan menganggap dua gerai tersebut tidak memberikan kontribusi pendapatan 
signifikan. Kinerja keuangan per semester I2017, penjualan Matahari Department Store menyusut 27,4\% menjadi Rp3,76 triliun jika dibandingkan dengan periode sama tahun sebelumnya.

PT Mitra Adiperkasa Tbk (MAPI) juga mengalami nasib yang sama sebagai induk pusat perbelanjaan Lotus mengumumkan semua gerai Lotus ditutup. Setelah dua gerai sudah lebih dulu tutup, tiga gerai lainnya akhir Oktober 2017 menyusul ditutup. Tiga gerai itu berlokasi di Thamrin Jakarta, Bekasi, dan Cibubur. Selain Lotus, MAPI juga merencanakan menutup satu gerai Debenhams tersisa di Indonesia yakni gerai di Senayan City pada akhir tahun 2017. Dua gerai Debenhams lainnya di Kemang Village dan Supermall Karawaci sebelumnya sudah lebih dulu ditutup (www.sindonews.com, 2017).

Perusahaan retail yang telah beroperasi dalam jangka waktu tertentu terpaksa harus bubar karena mengalami financial distress yang berujung pada kebangkrutan yang mengakibatkan penutupan gerai dan toko retail. Permasalahan yang terjadi pada perusahaan retail Indonesia terjadi karena banyak faktor yang menjadi penyebab perusahaan retail mengalami kesulitan keuangan dan memutuskan untuk bubar.

Perkembangan era digital saat ini sangat mempengaruhi industri retail di Indonesia. Banyaknya bisnis berbasis online menyebabkan industri retail mengalami pelemahan daya beli serta menjadi faktor utama penurunan pertumbuhan industri retail. Selain munculnya pergeseran ke online, biaya produksi juga menjadi salah satu penyebab yang cukup mempengaruhi dikarenakan terjadinya perubahan konsumen (Nilasari dan Mulyo, 2018:2).

Pengenalan lebih awal mengenai kondisi financial distress yang dialami suatu perusahaan dapat dilakukan menggunakan model sistem peringatan dini atau early warning system (Nilasari dan Mulyo, 2018:3). Model ini dapat digunakan sebagai alat untuk mengenali gejala awal kondisi financial distress untuk selanjutnya dilakukan upaya memperbaiki kondisi sebelum sampai pada kondisi krisis atau kebangkrutan. Menurut Platt dan Platt (dalam Nilasari dan Mulyo, 2018:2), financial distress merupakan tahapan penurunan kondisi keuangan suatu perusahaan sebelum terjadinya kebangkrutan. Financial distress dapat digambarkan sebagai suatu kondisi bilamana perusahaan mengalami laba bersih operasi (net operation income) negatif selama beberapa tahun dan selama lebih dari satu tahun tidak melakukan pembayaran dividen.

\section{Metode Analisis Financial Distress (Kesulitan Keuangan) Altman Z-Score \\ Bambang Hermanto dan Mulyo Agung (2015:241) analisis Altman Z-Score adalah suatu alat yang digunakan untuk meramalkan tingkat kebangkrutan suatu perusahaan dengan menghitung nilai dari}


beberapa rasio kemudian dimasukan dalam suatu persamaan diskriminan. Perhitungan nilai $\mathrm{Z}$ dapat diperoleh dari rumus formula sebagai berikut:


EBIT/TA +0,420 MVE/BVD +0,998 S/TA

Keterangan :

1. WC/TA : Working Capital to Total Assets (perbandingan antara modal kerja bersih dan total aktiva) sebagai $\mathrm{X} 1$.

2. RE/TA : Retained Earning to Total Assets (perbandingan antara saldo laba dan total aktiva) sebagai X2.

3. EBIT/TA : Earning Before Interest and Tax to Total Assets (perbandingan antara laba sebelum biaya bunga dan pajak dengan total aktiva sebagai X3.

4. MVE/ BVD : Market Value Equity to Book Value of Debt (perbandingan antara nilai pasar modal dan nilai buku hutang) sebagai X4.

5. S/TA : Sales to Total Assets (perbandingan antara penjualan dan total aktiva) sebagai X5.

Dari metode Altman Z-Score tersebut, maka kondisi perusahaan dibagi menjadi tiga kategori (Bambang Hermanto dan Mulyo Agung, 2015:242), yaitu :

1. Apabila nilai Z-Score di atas 2,90 (ZScore $>2,90$ ) diklasifikasikan sebagai perusahaan yang sehat.

2. Apabila nilai Z-Score antara 1,20 sampai 2,90 (1,20<Z-Score<2,90) diklasifikasikan sebagai perusahaan yang berada dalam daerah kelabu (grey area). Pada kondisi ini, perusahaan mengalami masalah keuangan yang harus ditangani dengan penanganan manajemen yang tepat. Kalau terlambat dan tidak cepat penanganannya, maka perusahaan dapat mengalami kebangkrutan.

3. Apabila nilai Z-Score di bawah 1,20 (ZScore $<1,20)$ diklasifikasikan sebagai perusahaan yang berpotensi mengalami financial distress.

\section{HASIL PENELITIAN}

Bursa Efek Indonesia Sub-Sector Retail Trade

Perusahaan yang terdaftar di BEI subsektor Retail Trade sebanyak 25 perusahaan. Namun, sesuai dengan kriteria pemilihan sampel dengan teknik purposive sampling.

Kriteria sampel perusahaan yang digunakan dalam penelitian ini antara lain :

1. Perusahaan retail trade yang terdaftar di Bursa Efek Indonesia periode tahun 20142017.

2. Perusahaan yang tidak delisting dari Bursa Efek Indonesia periode tahun 2014-2017.

3. Perusahaan retail trade yang menerbitkan laporan keuangan berturut-turut dari tahun 2014-2017 yang terdiri dari laporan labarugi, laporan posisi keuangan, laporan perubahan modal, dan laporan trading shares activities perusahaan.

Berdasarkan kriteria di atas, dari 25 (dua puluh lima) perusahaan hanya 17 (tujuh belas) perusahaan sub-sektor retail trade yang memenuhi syarat dan bisa dilakukan analisis Altman Z-Score untuk periode tahun 20142017. Daftar perusahaan sub-sektor retail trade dalam penelitian ini antara lain ACES (PT.Ace Hardware Indonesia Tbk), AMRT (PT. Sumber Alfaria Trijaya Tbk), CENT (PT 
Centratama Telekomunikasi Indonesia Tbk), CSAP (PT. Catur Sentosa Adiprana Tbk), ECII (PT. Electronic City Indonesia Tbk), ERAA (PT. Erajaya Swasembada Tbk), GOLD (PT. Golden Retailindo Tbk), HERO (PT. Hero Supermarket Tbk), KOIN (PT. Kokoh Inti Arebama Tbk), LPPF (PT. Matahari Department Store Tbk), MAPI (PT. Mitra Adiperkasa Tbk), MPPA (PT. Matahari Putra Prima Tbk), RALS (PT. Ramayana Lestari Sentosa Tbk), RANC (PT. Supra Boga Lestari Tbk), RIMO (PT. Rimo International Lestari Tbk), SONA (PT. Sona Topas Tourism Industry Tbk) dan TELE (PT. Tiphone Mobile Indonesia Tbk).

\section{HASIL ANASLISA DATA}

Teknik analisis data yang digunakan dalam penelitian ini adalah teknik analisis deskriptif yang bertujuan untuk mengumpulkan data dan data yang telah dikumpulkan kemudian diolah dan disajikan kembali dengan disertai hasil analisis pembahasan sehingga dapat memberikan gambaran yang jelas. Pengolahan data dalam penelitian ini menggunakan Microsoft Excel 2016.

\section{Hasil Analisis Data WC/TA : Working} Capital to Total Assets (X1)

Perhitungan analisis data $\mathrm{X} 1$ diperoleh dari rasio perbandingan antara Working Capital (Modal Kerja) dengan Total Assets (Total Aktiva). Hasil analisis X1 menjelaskan bahwa terdapat 6 (enam) perusahaan yang memiliki nilai rasio Working Capital to Total Assets sangat rendah bahkan bernilai negatif (-), perusahaan pertama adalah AMRT tahun 2014 dengan nilai rasio -0,052, tahun 2016 dengan nilai rasio -0,061, dan tahun 2017 dengan nilai rasio $-0,069$. Perusahaan kedua adalah CENT tahun 2014 dengan nilai rasio 0,085 . Perusahaan ketiga adalah GOLD tahun 2016 dengan nilai rasio -0,124 dan tahun 2017 dengan nilai rasio $-0,138$. Perusahaan keempat adalah LPPF tahun 2014 dengan nilai rasio 0,117 dan tahun 2015 dengan nilai $-0,043$. Perusahaan kelima adalah MPPA tahun 2017 dengan nilai rasio $-0,256$. Perusahaan keenam adalah RIMO tahun 2014 dengan nilai rasio 8,010 , tahun 2015 dengan nilai rasio $-1,961$, dan tahun 2016 dengan nilai rasio -1,504.

Hasil Analisis Data RE/TA : Retained Earning to Total Assets (perbandingan antara saldo laba dan total aktiva) (X2.)

Perhitungan analisis data X2 diperoleh dari rasio perbandingan antara Retained Earning (Laba Ditahan) dengan Total Assets (Total Aktiva). Hasil analisis X2 menjelaskan bahwa terdapat 2 (dua) perusahaan yang memiliki nilai rasio Retained Earning to Total Assets sangat rendah bahkan bernilai negatif (-), perusahaan pertama adalah CENT tahun 2014 dengan nilai rasio $-0,053$, tahun 2015 dengan nilai rasio $-0,079$, tahun 2016 dengan nilai rasio $-0,100$, dan tahun 2017 dengan nilai rasio $-0,056$. Perusahaan kedua adalah RIMO tahun 2014 dengan nilai rasio $-24,417$, tahun 2015 dengan nilai rasio - 
6,471, tahun 2016 dengan nilai rasio $-37,354$, dan tahun 2017 dengan nilai rasio -0,208.

\section{Hasil Analisa Data EBIT/TA : Earning} Before Interest and Tax to Total Assets (perbandingan antara laba sebelum biaya bunga dan pajak dengan total aktiva (X3)

Perhitungan analisis data X3 diperoleh dari rasio perbandingan antara Earning Before Interest \& Tax (Laba Sebelum Bunga \& Pajak) dengan Total Assets (Total Aktiva). Hasil analisis X3 menjelaskan bahwa terdapat 4 (empat) perusahaan yang memiliki nilai rasio Earning Before Interest \& Tax to Total

Hasil Analisis Data 4. MVE/BVD : Market Value Equity to Book Value of Debt (perbandingan antara nilai pasar modal dan nilai buku hutang) (X4.)

Perhitungan analisis data X4 diperoleh dari rasio perbandingan antara Market Value Equity (Nilai Pasar Modal) dengan Book Value of Debt (Nilai Buku Hutang). Hasil analisis X4 menjelaskan bahwa terdapat 1 (satu) perusahaan yang tidak memiliki nilai rasio Market Value Equity to Book Value of Debt karena tidak menerbitkan saham yaitu RIMO tahun 2015 dan tahun 2016.

Hasil Analisis Data S/TA : Sales to Total Assets (perbandingan antara penjualan dan total aktiva( (X5)

Perhitungan analisis data X5 diperoleh dari rasio perbandingan antara Sales
Assets sangat rendah bahkan bernilai negatif(), perusahaan pertama adalah CENT tahun 2014 dengan nilai rasio $-0,027$, tahun 2015 dengan nilai rasio $-0,028$, tahun 2016 dengan nilai rasio -0,015, dan tahun 2017 dengan nilai rasio -0,004. Perusahaan kedua adalah GOLD tahun 2015 dengan nilai rasio $-0,090$, tahun 2016 dengan nilai rasio $-0,042$. Perusahaan ketiga adalah MPPA tahun 2017 dengan nilai rasio $-0,287$. Perusahaan keempat adalah RIMO tahun 2014 dengan nilai rasio -0,621, tahun 2015 dengan nilai rasio $-0,176$, dan tahun 2016 dengan nilai rasio $-0,093$.

(Penjualan) dengan Total Assets (Total Aktiva). Hasil analisis X5 menjelaskan bahwa terdapat 1 (satu) perusahaan yang memiliki nilai rasio Sales to Total Assets rendah yaitu RIMO pada tahun 2016 dengan nilai rasio 0,001 .

\section{Hasil Analisis Altman Z-Score}

Perhitungan analisis Altman Z-Score yang dilakukan terhadap perusahaan subsektor Retail yang terdaftar di Bursa Efek Indonesia periode tahun 2014-2017 dengan ketentuan menggunakan rumus sebagai berikut :

$\mathrm{Z}=0,717 \times 1+0,847 \times 2+3,107 \times 3+0,420 \times 4$ $+0,998 \times 5$

Perhitungan tersebut diperoleh dari 5 (lima) rasio perbandingan yaitu X1 dengan rasio Working Capital to Total Assets, X2 dengan rasio Retained Earning to Total Assets, X3 dengan rasio Earning Before 
Interest \& Tax to Total Assets, X4 dengan rasio Market Value Equity to Book Value of Debt, dan X5 dengan rasio Sales to Total Assets.

Berdasarkan barkan hasil bahwa terdapat 3 (tiga) perusahaan yang mengalami kondisi financial distress antara lain : CENT selama 4 tahun (tahun 2014-2017), GOLD selama 3 tahun (tahun 2015-2017), dan RIMO selama 3 tahun (tahun 2014-2016). Sementara itu, terdapat 6 (enam) perusahaan yang mengalami kondisi grey area antara lain : CSAP selama 4 tahun (tahun 2014-2017), ECII selama 3 tahun (tahun 2015-2017), GOLD selama 1 tahun (tahun 2014), MPPA selama 2 tahun (tahun 2016-2017), RALS selama 2 tahun (tahun 2014-2015), dan SONA selama 4 tahun (tahun 2014-2017).

\section{PEMBAHASAN}

Altman Z-Score merupakan suatu alat analisis yang digunakan untuk meramalkan tingkat kebangkrutan atau kesulitan keuangan suatu perusahaan dengan menghitung nilai dari 5 (lima) rasio kemudian dimasukan dalam suatu persamaan diskriminan. Perhitungan nilai $\mathrm{Z}$ dapat diperoleh dari rumus formula sebagai berikut.

$$
\begin{aligned}
Z & =0,717 X 1+0,847 \times 2+3,107 \times 3+0,420 \\
X 4 & +0,998 \times 5
\end{aligned}
$$

Hasil perhitungan nilai Altman ZScore kondisi perusahaan dikategorikan menjadi tiga kategori yaitu : a. Apabila nilai Z-Score di atas 2,90 (ZScore $>2,90$ ) diklasifikasikan sebagai perusahaan yang sehat.

b. Apabila nilai Z-Score antara 1,20 sampai 2,90 (1,20<Z-Score<2,90) diklasifikasikan sebagai perusahaan yang berada dalam daerah kelabu (grey area). Pada kondisi ini, perusahaan mengalami masalah keuangan yang harus ditangani dengan penanganan manajemen yang tepat. Kalau terlambat dan tidak cepat penanganannya, maka perusahaan dapat mengalami kebangkrutan.

c. Apabila nilai Z-Score di bawah 1,20 (ZScore $<1,20$ ) diklasifikasikan sebagai perusahaan yang berpotensi mengalami financial distress.

Berdasarkan perhitungan tabel 4 menunjukkan bahwa ada perusahaan Retail yang terdaftar di BEI periode tahun 20142017 yang mengalami kondisi financial distress yaitu CENT selama 4 tahun berturutturut tahun 2014-2017, GOLD selama 3 tahun berturut-turut tahun 2015-2017, dan RIMO selama 3 tahun berturut-turut tahun 20142016. Hal ini tergambar dari hasil perhitungan Z-Score yang bernilai kurang dari 1,20 $(Z<1,20)$, perusahaan yang pertama adalah CENT memperoleh nilai Z-Score sebesar 0,199 (tahun 2014), nilai Z-Score sebesar 0,114 (tahun 2015), nilai Z-Score sebesar 0,551 (tahun 2016), dan nilai Z-Score sebesar 0,236 (tahun 2017). Perusahaan yang kedua adalah GOLD memperoleh nilai Z-Score sebesar 1,066 (tahun 2015), nilai Z-Score 
sebesar 1,047 (tahun 2016), dan nilai Z-Score sebesar 0,239 (tahun 2017). Perusahaan yang ketiga adalah RIMO memperoleh nilai ZScore sebesar -28,293 (tahun 2014), nilai ZScore sebesar -7,432 (tahun 2015), dan nilai Z-Score sebesar -33,004 (tahun 2016).

Perusahaan Retail yang terdaftar di BEI periode tahun 2014-2017 yang mengalami kondisi grey area yaitu CSAP selama 4 tahun berturut-turut tahun 20142017, ECII selama 3 tahun berturut-turut tahun 2015-2017, GOLD pada tahun 2014, MPPA selama 2 tahun berturut-turut tahun 2016-2017, RALS selama 2 tahun berturutturut tahun 2014-2015, dan SONA selama 4 tahun berturut-turut tahun 2014-2017. Hal ini tergambar dari hasil perhitungan Z-Score yang bernilai antara 1,20 sampai 2,90 $(1,20<$ Z-Score $<2,90)$, perusahaan yang pertama adalah CSAP memperoleh nilai ZScore sebesar 2,641 (tahun 2014), nilai ZScore sebesar 2,503 (tahun 2015), nilai ZScore sebesar 2,353 (tahun 2016), dan nilai ZScore sebesar 2,137 (tahun 2017). Perusahaan yang kedua adalah ECII memperoleh nilai ZScore sebesar 2,864 (tahun 2015), nilai ZScore sebesar 2,017 (tahun 2016), dan nilai ZScore sebesar 2,120 (tahun 2017). Perusahaan ketiga adalah GOLD memperoleh nilai ZScore sebesar 1,328 (tahun 2014). Perusahaan keempat adalah MPPA memperoleh nilai ZScore sebesar 2,645 (tahun 2016) dan nilai ZScore sebesar 1,380 (tahun 2017). Perusahaan kelima adalah RALS memperoleh nilai ZScore sebesar 2,855 (tahun 2014) dan nilai Z-
Score sebesar 2,752 (tahun 2015). Perusahaan keenam adalah SONA memperoleh nilai ZScore sebesar 2,554 (tahun 2014), nilai ZScore sebesar 2,235 (tahun 2015), nilai ZScore sebesar 1,993 (tahun 2016), dan nilai ZScore sebesar 2,245 (tahun 2017).

Altman Z-Score menghasilkan suatu prediksi mengenai masalah financial distress yang terdiri dari rasio-rasio keuangan dengan menggunakan perhitungan Working Capital to Total Assets sebagai X1, Retained Earning to Total Assets sebagai X2, Earning Before Interest and Tax to Total Assets sebagai X3, Market Value Equity to Book Value of Debt sebagai X4 dan Sales to Total Assets sebagai $X 5$. Berikut dapat dijelaskan indikator financial distress dari masing-masing rasio keuangan metode Altman Z-Score.

Working Capital to Total Assets sebagai X1 merupakan rasio likuiditas yang digunakan untuk mengukur kemampuan perusahaan dalam memenuhi kewajiban jangka pendeknya. Rasio ini merupakan variabel X1 dari multivariate diskriminan analysis yang ada dalam penelitian Altman ZScore. Rasio ini dapat dicari dengan cara membandingkan Modal Kerja bersih terhadap Total Aktiva perusahaan. Working Capital bisa diperoleh dengan cara Total Current Asset (Total Aktiva Lancar) dikurangi dengan Total Current Liabilities (Total Hutang Lancar). Semakin kecil rasio ini menunjukkan kondisi likuiditas perusahaan semakin buruk, kondisi ini menggambarkan kemungkinan besar perusahaan akan mengalami masalah 
dalam menutupi kewajiban jangka pendeknya yang disebabkan tidak tersedianya aset lancar yang cukup untuk menutup kewajiban lancar tersebut.

Hasil perhitungan menunjukkan bahwa 6 (enam) perusahaan memiliki nilai rasio Working Capital to Total Assets negatif (-) antara lain AMRT pada tahun 2014 dengan rasio $-0,052$, tahun 2015 dengan rasio $-0,061$ dan tahun 2017 dengan rasio $-0,069$. Perusahaan kedua adalah CENT pada tahun 2014 dengan rasio $-0,085$. Perusahaan ketiga adalah GOLD pada tahun 2016 dengan rasio 0,124 dan tahun 2017 dengan rasio $-0,138$. Perusahaan keempat adalah LPPF pada tahun 2014 dengan rasio $-0,117$ dan tahun 2015 dengan rasio $-0,043$. Perusahaan kelima adalah MPPA pada tahun 2017 dengan rasio 0,256 . Perusahaan keenam adalah RIMO pada tahun 2014 dengan rasio -8,010, tahun 2015 dengan rasio -1,961, dan tahun 2016 dengan rasio $-1,504$. Hal ini menggambarkan kondisi likuiditas perusahaan yang buruk menyebabkan perusahaan mengalami masalah dalam menutup hutang lancar yang disebabkan tidak tersedianya aktiva lancar yang cukup untuk menutup kewajiban lancar tersebut. Perusahaan memiliki tingkat likuiditas yang sangat rendah karena total hutang lancar yang dimiliki melebihi total aktiva.

Retained Earning to Total Assets sebagai X2 merupakan merupakan rasio profitabilitas yang mendeteksi kemampuan perusahaan dalam menghasilkan keuntungan atau laba. Retained Earning merupakan laba yang tidak dibagikan kepada para pemegang saham. Rasio ini dapat dicari dengan membandingkan nilai Laba Ditahan terhadap Total Aktiva perusahaan. Semakin besar rasio ini menunjukkan kinerja perusahaan semakin baik karena besarnya peranan laba ditahan dalam membentuk dana perusahaan. Perhitungan tabel 4 menunjukkan bahwa 2 (dua) perusahaan memiliki nilai rasio Retained Earning to Total Assets negatif (-) antara lain CENT pada tahun 2014 dengan rasio $-0,053$, tahun 2015 dengan rasio $-0,079$, tahun 2016 dengan rasio $-0,100$, dan tahun 2017 dengan rasio $-0,056$. Perusahaan kedua adalah RIMO pada tahun 2014 dengan rasio 24,417 , tahun 2015 dengan rasio $-6,471$, tahun 2016 dengan rasio $-37,354$, dan tahun 2017 dengan rasio $-0,208$. Hal ini menggambarkan bahwa kemampuan perusahaan mengakumulasikan laba ditahan sangat rendah karena pendapatan perusahaan tidak mampu menutupi biaya atau beban usaha.

Earning Before Interest and Tax to Total Assets sebagai X3 merupakan rasio yang mengukur kemampuan operasional perusahaan dalam menghasilkan laba dari total aktiva yang digunakan sebelum beban pajak. Rasio ini dihitung dengan membandingkan jumlah Laba Sebelum Bunga \& Beban Pajak terhadap Total Aktiva yang dimiliki. Semakin besar rasio ini berarti semakin baik kinerja perusahaan dalam menggunakan aktivanya. Perhitungan tabel 4 menggambarkan bahwa 4 (empat) perusahaan 
memiliki nilai rasio Earning Before Interest and Tax to Total Assets negatif (-) antara lain CENT pada tahun 2014 dengan rasio $-0,027$, tahun 2015 dengan rasio $-0,028$, tahun 2016 dengan rasio $-0,015$, dan tahun 2017 dengan rasio -0,004. Perusahaan kedua adalah GOLD pada tahun 2015 dengan rasio $-0,090$ dan tahun 2016 dengan rasio $-0,042$. Perusahaan ketiga adalah MPPA pada tahun 2017 dengan rasio $-0,287$. Perusahaan keempat adalah RIMO pada tahun 2014 dengan rasio $-0,621$, tahun 2015 dengan rasio $-0,176$, dan tahun 2016 dengan rasio $-0,093$. Hal ini menggambarkan kinerja perusahaan kurang baik dalam mengelola aktivanya. Berdasarkan rasio laba sebelum beban pajak terhadap total aktiva dapat diketahui tingkat efisiensi manajemen dalam memperoleh laba/rugi operasi dari aset yang dimiliki. Hasil yang negatif dari rasio ini menunjukkan perusahaan mempunyai biaya operasi lebih besar dari laba kotornya, sedangkan yang mempunyai nilai positif menunjukkan laba kotor perusahaan lebih besar dari biaya operasinya.

Market Value Equity to Book Value of Total Debt sebagai X4 merupakan rasio yang digunakan untuk mengukur tingkat kemampuan perusahaan dalam memenuhi setiap kewajibannya yang meliputi hutang jangka pendek dan hutang jangka panjang dengan modal sendiri yang dimiliki. Semakin besar rasio ini akan mempengaruhi keamanan dana dari suatu perusahaan. Perhitungan tabel 4 menunjukkan bahwa 1 (satu) perusahaan yang memiliki nilai rasio Market Value Equity to Book Value of Total Debt bernilai 0 antara lain RIMO pada tahun 2015 dan 2016. Hal ini menunjukkan bahwa perusahaan tersebut tidak menerbitkan saham dan memiliki nilai buku hutang yang melebihi nilai pasar modal yang dimiliki, sehingga nilai rasio Market Value Equity to Book Value of Total Debt 0.

Sales to Total Assets sebagai X5 merupakan rasio yang digunakan untuk mengukur tingkat kemampuan perusahaan dalam mengelola total aktiva untuk mendapatkan penjualan yang maksimal. Semakin besar rasio ini berarti perusahaan dapat mengelola aktiva yang dimilikinya dengan baik. Perhitungan tabel 4 menunjukkan bahwa 4 (empat) perusahaan memiliki nilai rasio Sales to Total Assets rendah antara lain CENT pada tahun 2014 dengan rasio 0,081 , tahun 2015 dengan rasio 0,081, tahun 2016 dengan rasio 0,107 , dan tahun 2017 dengan rasio 0,158. Perusahaan kedua adalah ECII pada tahun 2015 dengan nilai rasio 0,938, tahun 2016 dengan rasio 0,882, dan tahun 2017 dengan rasio 0,957. Perusahaan ketiga adalah GOLD pada tahun 2014 dengan rasio 0,482, tahun 2015 dengan rasio 0,573 , tahun 2016 dengan rasio 0,064 , dan tahun 2017 dengan rasio 0,147. Perusahaan keempat adalah RIMO pada tahun 2014 dengan rasio 0,018 , tahun 2015 dengan rasio 0,004 , tahun 2016 dengan rasio 0,001 , dan tahun 2017 dengan rasio 0,048. Hal ini menggambarkan bahwa perusahaan yang memiliki rasio Sales to Total Assets rendah, maka perusahaan tidak dapat mengoptimalkan 
dan mengelola total aktiva dengan baik, sehingga nilai penjualan sangat rendah jika dibandingkan dengan nilai total aktiva yang dimiliki.

\section{KESIMPULAN DAN SARAN KESIMPULAN}

Berdasarkan dari hasil analisis dan pembahasan mengenai analisis financial distress dengan metode Altman Z-Score yang dilakukan terhadap perusahaan retail trade periode tahun 2014-2017 dapat ditarik kesimpulan sebagai berikut :

Perusahaan sub-sector retail trade yang terindikasi mengalami kondisi financial distress antara lain.

1. PT Centratama Telekomunikasi Indonesia Tbk (CENT) selama 4 tahun berturut-turut tahun 2014-2017. Hasil perhitungan ZScore yang bernilai kurang dari 1,20 $(Z<1,20)$, CENT memperoleh nilai $Z$ Score sebesar 0,199 (tahun 2014), nilai ZScore sebesar 0,114 (tahun 2015), nilai ZScore sebesar 0,551 (tahun 2016), dan nilai Z-Score sebesar 0,236 (tahun 2017).

2. PT Golden Retailindo Tbk (GOLD) selama 3 tahun berturut-turut tahun 2015-2017. Hasil perhitungan Z-Score yang bernilai kurang dari 1,20 $(\mathrm{Z}<1,20)$, GOLD memperoleh nilai Z-Score sebesar 1,066 (tahun 2015), nilai Z-Score sebesar 1,047 (tahun 2016), dan nilai Z-Score sebesar 0,239 (tahun 2017).

3. PT Rimo International Lestari Tbk (RIMO) selama 3 tahun berturut-turut tahun 2014-2016. Hasil perhitungan ZScore yang bernilai kurang dari 1,20 $(Z<1,20)$, RIMO memperoleh nilai $Z$ Score sebesar -28,293 (tahun 2014), nilai Z-Score sebesar -7,432 (tahun 2015), dan nilai Z-Score sebesar -33,004 (tahun 2016).

Sedangkan perusahaan sub-sector retail trade yang terindikasi mengalami kondisi grey area antara lain.

1. PT Catur Sentosa Adiprana Tbk (CSAP) selama 4 tahun berturut-turut tahun 20142017. Hasil perhitungan Z-Score yang bernilai antara 1,20 sampai 2,90 $(1,20<\mathrm{Z}$ Score $<2,90$ ), CSAP memperoleh nilai ZScore sebesar 2,641 (tahun 2014), nilai ZScore sebesar 2,503 (tahun 2015), nilai ZScore sebesar 2,353 (tahun 2016), dan nilai Z-Score sebesar 2,137 (tahun 2017)

2. PT Electronic City Indonesia Tbk (ECII) selama 3 tahun berturut-turut tahun 20152017. Hasil perhitungan Z-Score yang bernilai antara 1,20 sampai 2,90 $(1,20<\mathrm{Z}$ Score $<2,90$ ), ECII memperoleh nilai ZScore sebesar 2,864 (tahun 2015), nilai ZScore sebesar 2,017 (tahun 2016), dan nilai Z-Score sebesar 2,120 (tahun 2017).

3. PT Golden Retailindo Tbk (GOLD) pada tahun 2014. Hasil perhitungan Z-Score yang bernilai antara 1,20 sampai 2,90 $(1,20<$ Z-Score $<2,90)$, GOLD memperoleh nilai Z-Score sebesar 1,328 (tahun 2014).

4. PT Matahari Putra Prima Tbk (MPPA) selama 2 tahun berturut-turut tahun 20162017. Hasil perhitungan Z-Score yang 
bernilai antara 1,20 sampai $2,90(1,20<Z$ Score $<2,90$ ), MPPA memperoleh nilai ZScore sebesar 2,645 (tahun 2016) dan nilai Z-Score sebesar 1,380 (tahun 2017).

5. PT Ramayana Lestari Sentosa Tbk (RALS) selama 2 tahun berturut-turut tahun 20142015. Hasil perhitungan Z-Score yang bernilai antara 1,20 sampai $2,90(1,20<Z$ Score $<2,90$ ), RALS memperoleh nilai ZScore sebesar 2,855 (tahun 2014) dan nilai Z-Score sebesar 2,752 (tahun 2015).

6. PT Sona Topas Tourism Industry Tbk (SONA) selama 4 tahun berturut-turut tahun 2014-2017. Hasil perhitungan ZScore yang bernilai antara 1,20 sampai $2,90 \quad(1,20<$ Z-Score $<2,90), \quad$ SONA memperoleh nilai Z-Score sebesar 2,554 (tahun 2014), nilai Z-Score sebesar 2,235 (tahun 2015), nilai Z-Score sebesar 1,993 (tahun 2016), dan nilai Z-Score sebesar 2,245 (tahun 2017).

\section{SARAN}

Berdasarkan dari kesimpulan yang telah diulas di atas, maka penulis dapat mengajukan saran-saran sebagai berikut:

1. Bagi perusahaan yang terindikasi mengalami kondisi financial distress dan grey area sebaiknya melakukan evaluasi dalam manajemen perusahaan dengan segera menindaklanjuti masalah internal dalam perusahaan sehingga dapat mencegah adanya suatu kebangkrutan, misalnya dengan cara mengurangi liabilitas dan meningkatkan penjualan perusahaan dengan melakukan efisiensi biaya agar tidak terjadi financial distress. Pihak manajemen dapat mengambil tindakan merger atau takeover agar perusahaan lebih mampu untuk membayar hutang dan mengelola perusahaan dengan lebih baik.

2. Bagi para investor yang ingin berinvestasi disarankan untuk lebih berhati-hati dalam memilih perusahaan dan dapat menggunakan hasil penelitian sebagai salah satu bahan acuan atau rujukan dalam membuat keputusan investasi serta memilih perusahaan terutama perusahaan yang menunjukkan peningkatan kinerja keuangan atau perusahaan yang memiliki kinerja keuangan baik menjadi pilihan yang lebih aman.

3. Bagi penelitian selanjutnya sebaiknya menambah periode pengamatan mengenai kondisi financial distress perusahaan dan dapat menambah metode analisis financial distress yang lain seperti metode Springate, Zmijewski, Olhson dan Grover.

\section{DAFTAR PUSTAKA}

Agustinova, Danu Eko. 2015. Memahami Metode Penelitian Teori \& Praktik. Yogyakarta:Calpulis.

Arista, Tiara Weni dan Triyonowati. 2016. Analisis Diskriminan Altman Z-Score untuk Memprediksi Kebangkrutan pada Perusahaan Ritel Go Public. Surabaya:Jurnal Ilmu dan Riset Manajemen STIESIA Surabaya, Vol.5, No.2, Februari 2016, ISSN:2461-0593 
Finance, Detik. 2017. Ini Jajaran Ritel yang Tutup Toko di Indonesia. Jakarta:Website. https://finance.detik.com/beritaekonomi-bisnis/d-3736180/ini-jajaranritel-yang-tutup-toko-di-indonesia/l. Diakses: 31 Maret 2018

2018. 50 Toko Ritel Ramairamai Tutup, Ada Apa? Jakarta:Website.

https://finance.detik.com/beritaekonomi-bisnis/d-3800037/50-tokoritel-ramai-ramai-tutup-ada-apa . Diakses: 31 Maret 2018.

Hermanto, Bambang dan Mulyo Agung. 2015. Analisa Laporan Keuangan. Jakarta:Lentera Ilmu Cendekia

Hikmawati, Fenti. 2017. Metodologi Penelitian. Depok:Rajawali Pers

Indonesia, Bursa Efek. 2018. Laporan Keuangan Perusahaan. Jakarta:Website. https://www.idx.co.id. Diakses: 31 Maret 2018.

Kasmir. 2016. Analisis Laporan Keuangan. Jakarta:Rajawali Pers

Masseleng, dkk. 2017. Pendeteksian Kebangkrutan Model Altman pada Perusahaan Properti dan Real Estate di BEI Periode 2011-2015. Manado:Jurnal EMBA Universitas Sam Ratulangi, Vol.5, No.2, Juni 2017, Hal.1041-1049, ISSN:2303-1174

Mulyadi, Roza. 2016. Pengaruh Rasio Profitabilitas Terhadap Penilaian Kinerja Model Z-Score Altman pada Perusahaan Farmasi di Bursa Efek Indonesia (BEI). Banten:Jurnal Akuntansi Universitas Ageng Tirtayasa, Vol.3, No.1, Januari 2016, ISSN:2339-2436.

Munawir. 2016. Analisa Laporan Keuangan.Yogyakarta:Liberty Yogyakarta
Nilasari, Devy dan Mulyo Haryanto. 2018. Memprediksi Perusahaan yang Berpotensi Mengalami Masalah Keuangan dengan Model Altman, Springate, dan Zmijewski (Studi pada Perusahaan Ritel yang Terdaftar di BEI Periode Tahun 2012-2016). Semarang:Jurnal STIE Universitas Diponegoro Semarang, Vol.10, No.1, Edisi Februari 2018, ISSN:2085-5656, e-ISSN:2232-826

Pura, Rahman. 2013. Pengantar Akuntansi 1 Pendekatan Siklus Akuntansi. Jakarta : Erlangga

Sarwono, Jonathan. 2013. Statistik Multivariat Aplikasi untuk Riset Skripsi. Yogyakarta:Andi Offset

Sindonews. 2017. Daftar Ritel di Indonesia yang Memilih Menutup Usaha. Jakarta:Website.

https://ekbis.sindonews.com/read/1253 581/34/daftar-ritel-di-indonesia-yangmemilih-menutup-usaha-1509533639. Diakses: 31 Maret 2018

Siregar, Syofian. 2015. Statistik Parametrik Untuk Penelitian Kuantitatif Dilengkapi dengan Perhitungan Manual dan Aplikasi SPSS Versi 17. Jakarta: Bumi Aksara

Sondakh,C.A, Sri.M, dan Y.Mandangie. 2014. Analisis Potensi Kebangkrutan Dengan Menggunakan Metode Altman Z-Score,Springate, dan Zmijewski Pada Industri Perdagangan Ritel Yang Terdaftar di BEI Periode 2009-2013. Manado:Jurnal EMBA Universitas Sam Ratulangi, Vol. 2 ,No.4, Desember 2014, Hlm. 364-373, ISSN 2303-1174

Subramanyam dan John Wild. 2016. Analisis Laporan Keuangan. Edisi 10. Jakarta: Salemba Empat

Sugiyono. 2010. Metode Penelitian Bisnis. Bandung:Alfabeta 
Sujarweni, Wiratna. 2015. Metodologi Penelitian Bisnis \& Ekonomi. Yogyakarta:Pustaka Baru Press

Swantari, Anita dan Fachrul Husain Habibie. 2012. Prediksi Financial Distress Berdasarkan Kemampuan Kinerja Keuangan pada Industri Property. Jakarta:E-Jurnal Sekolah Tinggi Pariwisata Trisakti, Vol. 3, No. 1 Januari 2012, Hlm. 1-18, ISSN 20865430

Utami, Nunik Setiyo. 2018. Analisa Kinerja Sektor Ritel Indonesia. Surabaya:Jurnal Sekolah Tinggi Ilmu Ekonomi Mahardika Surabaya, Vol.1, No.1, April 2018, Hal.43-48, ISSN:26156237. 